\title{
Protein corona: a new approach for nanomedicine design
}

\author{
This article was published in the following Dove Press journal: \\ International Journal of Nanomedicine \\ 18 April 2017 \\ Number of times this article has been viewed
}

\section{Van Hong Nguyen \\ Beom-Jin Lee}

Department of Pharmacy, Bioavailability Control Laboratory, College of Pharmacy, Ajou University, Suwon, Republic of Korea
Correspondence: Beom-Jin Lee Bioavailability Control Laboratory, College of Pharmacy, Ajou University, 206 Worldcup-road, Yeongtong-gu, Suwon 16499, Republic of Korea Tel +823 3I 2193442

Fax +82 3I 2 I 23653

Email bjl@ajou.ac.kr
Abstract: After administration of nanoparticle (NP) into biological fluids, an NP-protein complex is formed, which represents the "true identity" of NP in our body. Hence, protein-NP interaction should be carefully investigated to predict and control the fate of NPs or drug-loaded NPs, including systemic circulation, biodistribution, and bioavailability. In this review, we mainly focus on the formation of protein corona and its potential applications in pharmaceutical sciences such as prediction modeling based on NP-adsorbed proteins, usage of active proteins for modifying NP to achieve toxicity reduction, circulation time enhancement, and targeting effect. Validated correlative models for NP biological responses mainly based on protein corona fingerprints of NPs are more highly accurate than the models solely set up from NP properties. Based on these models, effectiveness as well as the toxicity of NPs can be predicted without in vivo tests, while novel cell receptors could be identified from prominent proteins which play important key roles in the models. The ungoverned protein adsorption onto NPs may have generally negative effects such as rapid clearance from the bloodstream, hindrance of targeting capacity, and induction of toxicity. In contrast, controlling protein adsorption by modifying NPs with diverse functional proteins or tailoring appropriate NPs which favor selective endogenous peptides and proteins will bring promising therapeutic benefits in drug delivery and targeted cancer treatment.

Keywords: protein-nanoparticle interaction, protein corona, exchange of adsorbed protein, toxicity reduction, predictive modeling, targeting drug delivery

\section{Introduction}

After systemic administration, nanomaterials are exposed to various physiological fluids, mostly blood. There are several thousand proteins in blood at up to a billion time differences in relative concentrations of protein corona. ${ }^{1}$ The adsorption of proteins on nanpoparticles (NPs) can modify the diverse physicochemical properties of NPs such as size, surface charge, surface composition, and functionality, hence giving NPs a new biological identity. This NP-protein complex, not bare NP, determines various biological responses such as fibrillation, cellular uptake, circulation time, bioavailability, and even toxicity. The layers consisting of bound or adsorbed proteins around NPs are called as protein corona. High surface energy may enhance the binding of protein on to NP surface.

Figure 1 shows the formation of protein corona and exchange of adsorbed proteins over time in biological conditions. Protein corona patterns mainly depend on the physicochemical properties of NPs (nanomaterial, size, charge, surface functional groups, shape) and exposing environments including immersed media components, temperature, $\mathrm{pH}$, dynamic shear stress, and interaction (or exposing) time. Proteins with large quantities are first bound to NP surface, and then gradually replaced by 
A

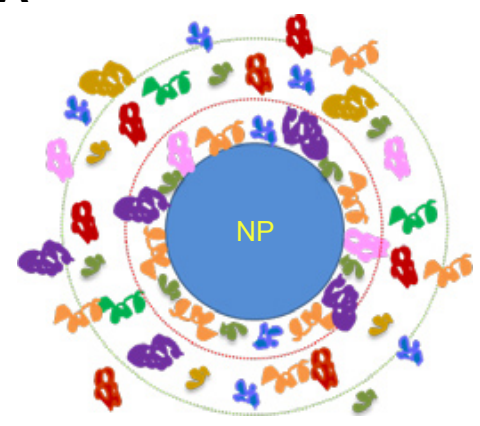

Immediate exposure
B

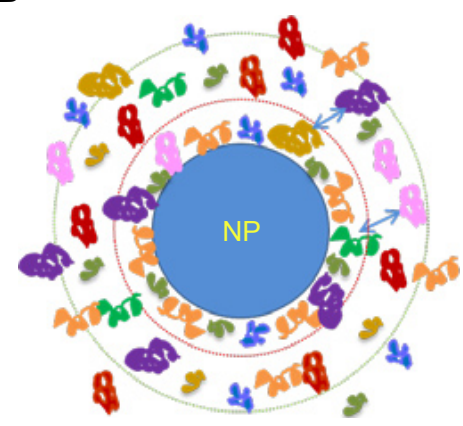

After a longer exposure
C

\section{Protein corona factors}

Nanoparticle Environment

Material

Composition

Surface

Size

Exposure time

Charge

$\mathrm{pH}$

Temperature

Shape

Shear stress

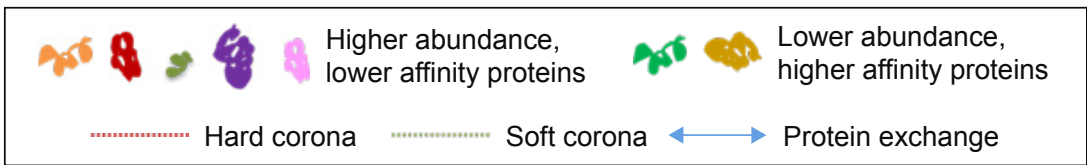

Figure I The formation of protein corona and exchange of adsorbed proteins over time in biological conditions.

Notes: (A) Immediately upon exposure. (B) After a longer exposure time, with displacement of proteins among the hard corona, soft corona, and cellular environment. (C) Major factors affecting protein corona pattern divided into two categorized properties: nanoparticle and environment.

Abbreviation: NP, nanoparticle.

higher affinity proteins (Vroman effect). ${ }^{2}$ The detailed information of protein corona is described in detail in the following section.

\section{Protein corona pattern}

The differences in NP properties and the environments influence protein corona by interacting with diverse protein compositions via adsorption. ${ }^{3}$ Additionally, protein corona is complex and unique to each nanomaterial and NP. Furthermore, the composition and relative quantity of adsorbed proteins may also not correspond with protein components and relative concentrations in exposure media. In other words, the adsorption of proteins onto NPs is controlled by the protein-NP interaction and protein-protein interaction. Table 1 shows the diversity of the top ten proteins adsorbed to silica NPs and the most abundant proteins in human plasma. Albumin is the most abundant protein in blood and is often found in protein corona fingerprints of various NPs. In addition, other common proteins to form adsorbed protein patterns include complement proteins, fibrinogen, and immunoglobulins, which significantly alter NP opsonization, allocation, and targeting efficiency. ${ }^{4,5}$ Protein pattern refers to some important and recognizable sequence features such as binding sites or the active sites of protein and enzymes because they have only a few amino acids that are essential for protein function.

Protein corona is divided into "hard corona" and "soft corona". Hard corona contains higher affinity proteins on the NP surface that may irreversibly bind to NPs. In contrast, soft corona formed by lower affinity proteins is reversibly bound

Table I Diversity of top ten proteins adsorbed to silica NPs and the most abundant proteins in human plasma

\begin{tabular}{|c|c|c|c|c|}
\hline \multirow[t]{2}{*}{ Number } & \multicolumn{3}{|c|}{$\begin{array}{l}\text { Top } 10 \text { most abundant corona proteins detectable after } 0.5 \text { min of plasma exposure to silica NPs } \\
\left(140 \mathrm{~nm} \text { ) with different surface functional groups }{ }^{23}\right.\end{array}$} & \multirow{2}{*}{$\begin{array}{l}\text { The } 10 \text { most } \\
\text { abundant proteins } \\
\text { in human plasma }\end{array}$} \\
\hline & Bare silica NPs & $\mathrm{NH}_{2}$ group & COOH group & \\
\hline 1 & Apolipoprotein B 100 & Apolipoprotein B 100 & Apolipoprotein B 100 & Albumin \\
\hline 2 & Complement factor $\mathrm{H}$ & Complement factor $\mathrm{H}$ & Complement factor $\mathrm{H}$ & Immunoglobulin G \\
\hline 3 & Fibronectin & Complement C3 & Complement C3 & Transferrin \\
\hline 4 & Complement C3 & Gelsolin & Fibronectin & Fibrinogen \\
\hline 5 & Gelsolin & Fibronectin & Gelsolin & Immunoglobulin A \\
\hline 6 & Complement C4 B & Apolipoprotein A & Coagulation factor $\mathrm{V}$ & $\alpha$-2-macroglobulin \\
\hline 7 & Apolipoprotein A & Thrombospondin & Thrombospondin I & Immunoglobulin $M$ \\
\hline 8 & Complement $\mathrm{CI}$ r subcomponent & Complement $\mathrm{CIr}$ subcomponent & Complement $\mathrm{CI}$ r subcomponent & $\alpha-$-I-Antitrypsin \\
\hline 9 & Thrombospondin I & Inter $\alpha$ trypsin inhibitor heavy chain $\mathrm{H} 4$ & Serum albumin & Complement $\mathrm{C} 3$ \\
\hline 10 & Prothrombin & Coagulation factor $V$ & Myosin 9 & Haptoglobin \\
\hline
\end{tabular}

Abbreviation: NP, nanoparticle. 
to NPs, which can be further exchangeable over time or easily detached by washing steps during experiments. Protein corona is a dynamic layer in which the arrangement and amount of protein are changeable according to the conditions of physicochemical and biological interaction.

\section{Protein conformation}

In general, protein conformation refers to the characteristic dimensional shapes or structures of a reversible protein formed by arrangement of amino acid molecules, including the secondary, super-secondary (motifs), tertiary (domains), and quaternary structure of the peptide chain. Reversible structural changes or alternative structures of the same protein are referred to as conformational isomers, or simply, conformations or conformational changes. Thus, protein functions depend on their secondary and tertiary structures. Hence, the change in protein structure can affect their pharmacological functions and activities due to the dynamic changes of exposing conditions. When the protein is bound to NPs to form protein corona, proteins may rearrange their structures to adapt to NPs surface and surrounding environments. This event is known as "conformational changes", in which the secondary and/or tertiary protein structure is modified. Proteins are required to interact with other biomolecules and substances to activate or express their biological functions. Therefore, a small modification in protein structure caused by mutual interaction with NPs may induce an enormous impact on their pharmacological activities, association with other proteins, and also other biological responses. ${ }^{6}$

The correlation between NP size and protein size is an important factor for determining protein structures. In case NPs are bigger than proteins, proteins may stretch to adapt to the NP surface. Smaller NPs decrease the interaction with proteins, causing less structural changes. ${ }^{7}$

The secondary structure of proteins is strongly affected by the surface charge of NPs. For example, gold NPs with identical properties, but different surface charges, showed similar adsorbed bovine serum albumin (BSA) amounts. However, the NPs having positive charges expressed much higher cell association and a faster cellular uptake rate than the negatively charged counterparts. This result suggested the internal structure modification of BSA might be caused by the NP charge. ${ }^{8}$ Indeed, adsorbed BSA onto negatively charged polystyrene NPs retains it native structure compared with the conformational change of BSA with positively charged NPs, which leads to the redirection of the protein-NP complex to scavenger receptors. The adsorbed BSA on anionic polystyrene NPs could inhibit cellular binding, but its counterpart enhanced the cellular binding of NPs and, unexpectedly, also toxicity. ${ }^{9}$ Consistently, other NPs carrying a negative charge, such as quantum dots decorated with carboxylate groups or gold NPs stabilized by citrate, inhibited cellular binding after incubation with serum proteins or BSA alone although the size, material, and surface modifications of NPs were diverse. ${ }^{10}$

\section{Instrumental analysis for evaluating protein corona}

The protein-NP interaction is studied by incubating NPs in protein solutions for a period of time, either a single protein solution such as BSA, fibronectin and $\mathrm{IgG},{ }^{11-14}$ or biological fluid containing multiple proteins such as serum, ${ }^{15,16}$ plasma, cytosol, ${ }^{17}$ fetal bovine serum (FBS), ${ }^{18}$ fetal calf serum, synovial fluid, and cerebrospinal fluid. ${ }^{19}$ Protein-NP complexes are then separated from the protein solution via instrumental analysis. The protein corona is widely characterized by total quantity, density, thickness, composition, relative abundance of each protein, protein binding affinity, and protein conformation.

The interaction between protein and NPs can be simply confirmed by the physical changes of NPs in size ${ }^{18}$ and zeta potential. ${ }^{20}$ Common techniques to evaluate NP size after protein adsorption include dynamic light scattering (DLS), transmission electron microscopy (TEM), and sometimes, atomic force microscopy (AFM). DLS is conventional and fast, but may be influenced by NP agglomeration, so that in several cases data collected by DLS and TEM are different. ${ }^{21}$ More advantageously, TEM and AFM give more clear information on single NP size, shape, and the protein corona covering the NP surface. The protein corona can be further characterized by UV-Vis absorption spectra. For example, Au NPs incubated with Dulbecco's Modified Eagle's Medium (DMEM) exhibited a slight red shift and higher absorption intensity over time in UV-Vis spectra than those that interacted with Roswell Park Memorial Institute (RPMI) medium. This suggests that a larger quantity of proteins were adsorbed on Au NPs when incubated with DMEM than RPMI. ${ }^{18}$

Centrifugation is the typical method to collect NP-protein complex from the interaction media and loosely adsorbed proteins, and sucrose cushion centrifugation allows the separation of complex in a short time (30 sec). ${ }^{11,12,22,23}$ The secondary structure of proteins can be evaluated by circular dichroism. However, this method cannot be used for a mixture of proteins due to its spectral complexity. Isothermal titration calorimetry (ITC) is another common method used to evaluate the molecular interaction between proteins and 
NPs. ${ }^{9,21,24-26}$ The positive points of the ITC method are that it directly characterizes and measures nanoparticle-protein interactions, such as total binding proteins and protein binding affinity, without using separation and isolation processes. $^{26}$

After separation of protein-NP complexes from incubation media or, isolation of protein from NP with further steps, electrophoresis was often applied for identification and qualitative determination of protein corona composition. ${ }^{19,24,25,27}$ In addition, gel filtration can be used to not only separate protein-NP complexes from incubation media, ${ }^{28,29}$ but also to isolate protein from NP surfaces as well as provide information of kinetic exchange rate for adsorbed proteins. ${ }^{30}$ A positive point about gel filtration is that it can both separate and isolate adsorbed proteins from easily deformed and low-density NPs such as liposomes and exosomes. Protein identification and quantity determination can be characterized by mass spectrometry, in which protein samples have been digested into small peptides and simply injected into analysis instrument. ${ }^{23,31}$ The protein corona results will be determined by comparison with standard protein data.

Protein corona evaluation may be obtained differently, depending on the types of applied analytical characterization. For example, human serum albumin (HSA) adsorbed on hydroxyethyl starch nanocapsules could be detected by ITC, while there was no trace of HSA when evaluated by SDS-PAGE. ${ }^{32}$ Hence, it is pivotal to choose suitable analytical techniques to accurately characterize protein corona properties since protein corona is related with physicochemical properties and biological identity of NPs.

\section{Effect of exposure conditions on protein corona Media composition}

Media with different protein components strongly affect protein corona properties. Interestingly, after only $1 \mathrm{~h}$ incubated in serum-free medium, the pristine NPs get coated by proteins located in either cell membrane or cytosol. Serum proteins adsorbed to silica NP surface showed reduced interaction with cells, resulting in lower cellular uptake of silica NPs in the media supplemented with serum compared with media with no serum addition. ${ }^{33}$ It was known that protein corona reduced the NP cell adhesion and cellular uptake. ${ }^{34}$ In another study, the influence of biological fluid in cellular uptake pathway of NPs on the evolution of the protein corona was examined after incubating NPs with plasma followed by cytosolic fluid. The protein corona of NPs after exposure to the cytosolic fluid was significantly different, but protein pattern in hard corona was retained after plasma incubation, ${ }^{17}$ which was in agreement with a previous study. ${ }^{35}$ DMEM encouraged higher total protein quantity adsorbed onto gold NPs than RPMI after $48 \mathrm{~h}$ incubation, but similar amounts were observed at the 1 -h incubation. ${ }^{18}$

\section{Protein concentrations}

The protein corona motif is significantly affected by the protein concentration. ${ }^{34}$ Silica NPs expressed different protein patterns when incubated with 3\%, 20\%, and 80\% plasma, explaining the replacement of proteins present in small quantities but with a higher binding affinity with proteins with lower binding affinity and higher concentrations in human plasma. ${ }^{27}$ Moreover, the higher human serum concentration in ranges of $0.5-50 \mathrm{wt} / \mathrm{v} \%$, gradually increase the relative abundance of Apo E compared to serum albumin and transferrin. It could be considered as the major proteins on the magnetic NP at $50 \%$ serum concentration. ${ }^{36}$ In contrast, phagocytosis of NPs by dendritic cells was identical in various concentrations of protein mixtures. This result could be explained by particle uptake by phagocytes, possibly not dependent on the total binding protein quantity but the abundance of recognizable proteins on the particle surface. ${ }^{37}$

\section{Exposure time}

Protein adsorption onto NPs is also controlled by the exposure time of NPs to the fluidic media. Protein corona is immediately formed when NPs come into contact with biological fluids. After only $30 \mathrm{sec}$ interaction with human plasma, nearly 300 proteins binding to NPs surface are detected. ${ }^{23}$ Longer duration of exposure time enhances the total protein quantity adsorbed. ${ }^{18}$ Additionally, the exchange of adsorbed proteins over time significantly modifies the abundance of each binding protein, hence resulting in different protein corona patterns. This can be explained by the replacement of higher affinity proteins to lower counterparts or favorable adsorption of lower molecular weight protein compared to higher ones. However, the composition of protein corona remains the same. ${ }^{18}$

\section{Static and fluidic conditions}

The difference in protein corona composition and quantity under static and flow conditions must be taken into account. Various previous studies on protein-NP interactions were often performed under static conditions, ${ }^{38}$ while NPs are often administrated through intravenous injection and immediately interact with blood protein under various shear stresses in the hydrodynamic body conditions. It is known that blood flow 
velocity ranges from $0.03 \mathrm{~cm} / \mathrm{sec}$ in capillaries to $15 \mathrm{~cm} / \mathrm{sec}$ in superior and inferior vena cava and $40 \mathrm{~cm} / \mathrm{sec}$ in the aorta. ${ }^{39,40}$ The protein corona of NPs under dynamic fluidic conditions is obviously different from the one constructed in static conditions. At $40 \mathrm{~cm} / \mathrm{sec}$, equal to abdominal aortic speed, the PEG-coated liposomes under dynamic fluidic conditions carried more negative charge compared to their static counterparts but their sizes were similar, suggesting the difference of binding protein components and each protein quantity. Additionally, the protein diversity in the protein corona under fluidic flow was considerably broadened. Therefore, it is essential to evaluate protein-NP interactions in a biomimetic environment which mimics in vivo physiological conditions to more accurately predict the fate of NPs in vivo. ${ }^{22}$

\section{Temperature}

Temperature also alters protein-NP interaction and was studied in several previous works. ${ }^{11,41,42}$ It was known that temperature caused significant changes in protein corona pattern of magnetic NPs in the human body temperature, ranging between $37^{\circ} \mathrm{C}$ and $41^{\circ} \mathrm{C}$ during exposure to various concentrations of HSA as well as apo-transferrin (apo-Tf). ${ }^{42}$ Protein quantity adsorbed on $\mathrm{Cu}$ NPs increased when incubation temperature increased from $15^{\circ} \mathrm{C}, 27^{\circ} \mathrm{C}$, and $37^{\circ} \mathrm{C}$ to $42^{\circ} \mathrm{C} .{ }^{41}$ Therefore, the health condition of the patients also needs to be considered, as fever or some diseases can change the body temperature which facilitates the NP interaction with protein, leading to changes in biodistribution and bioavailability of NPs.

\section{$\mathrm{pH}$ of biological media}

$\mathrm{pH}$ condition can be also considered as an important factor in the evaluation of the interaction of NPs with proteins. The change of environmental $\mathrm{pH}$ may alter protein binding affinity, ${ }^{43}$ leading to modification of adsorbed protein pattern. In the cellular uptake pathway, normally nanomaterials undergo several different $\mathrm{pH}$ of biological fluids such as blood (neutral $\mathrm{pH}$ ), exposure media ( $\mathrm{pH}$ 6.9-7.4), intracellular fluid (pH 6.8), and lysosome ( $\mathrm{pH} 4.5-5$ ). Additionally, upon administration, NPs enter the systemic blood circulation and are biodistributed to different organs. Cancer or tumor always produce an acid microenvironment and contain specific types of proteins which may particularly modify the protein corona around NPs, resulting in the changes of bioavailability and therapeutic response. Therefore, it is essential to focus on the effect of biological $\mathrm{pH}$ on protein-NP interactions for precise evaluation of NP fate inside our body.

\section{Effect of nanomaterial properties on protein corona formation}

It is well known that different characteristics of NPs produce different protein corona profiles. ${ }^{44}$ Hence, physicochemical and biological properties of NPs through NP-protein complexes can control cellular behavior, bioavailability, and biological responses. Table 2 shows the effect of various NP parameters on the changes of protein corona. Generally, hydrophobic nanomaterial mostly has a higher quantity of adsorbed proteins than the hydrophilic one. Therefore, protein corona around hydrophobic NPs may cause agglomeration and higher opsonization, leading to shorter systemic circulation time in

Table 2 Effect of NP parameters on the changes of protein corona

\begin{tabular}{|c|c|}
\hline NP parameter & Observed effects \\
\hline NP size & $\begin{array}{l}\text { - Bigger size, larger degree of protein coverage } e^{8,11,26,118} \\
\text { - Smaller size increases corona thickness and decreases conformational change } \\
\text { - Evolution of composition and relative abundance of adsorbed proteins }{ }^{23,122}\end{array}$ \\
\hline NP shape & Higher protein adsorption onto nanorods compared to nanospheres ${ }^{123}$ \\
\hline \multicolumn{2}{|l|}{ NP surface } \\
\hline Charge & $\begin{array}{l}\text { - Charge affects composition of formed protein corona } \\
\text { - More highly charged surfaces increase protein conformational changes } \\
\text { - Protein conformation: positive }>\text { negative }>\text { neutral } \\
\text { - Charged particles have higher cell internalization and faster opsonization rates than electrically } \\
\text { neutral particles; }{ }^{24} \text { positively charged NPs are incorporated by cells in higher numbers and faster than } \\
\text { negatively charged NPs }\end{array}$ \\
\hline Hydrophobicity & $\begin{array}{l}\text { Higher hydrophobic NPs: } \\
\text { - Increase adsorbed protein quantity }{ }^{13,26} \text { and qualitatively change obtained protein adsorption patterns }{ }^{125} \\
\text { - Increase affinities of biomolecules } \\
\text { - Increase protein conformational changes } \\
\text { - Are opsonized more quickly than hydrophilic NPs }\end{array}$ \\
\hline Smoothness/roughness & $\begin{array}{l}\text { Surface roughness greatly minimizes repulsive interaction and influences the amount of protein, but not } \\
\text { the protein identity }\end{array}$ \\
\hline
\end{tabular}

Abbreviation: NP, nanoparticle. 
blood than hydrophilic NPs. ${ }^{45}$ Even with lower amount of binding protein, hydrophilic nanomaterials adsorb proteins when exposed to the media that have commonly found proteins such as albumin, fibrinogen, and IgG. ${ }^{15}$ NPs with different functional groups on their surfaces can also carry individual protein "fingerprints" ${ }^{23}$ Protein fingerprint refers to an analytical technique or any of the several methods for identifying or differentiating proteins. Peptide fragments can form via chemical and enzymatic treatments, followed by separation and identification in a reproducible manner using protein mass spectrometry following SDS-PAGE, two-dimensional chromatography, and/or protein electrophoresis.

Notably, differences in mechanical properties of nanomaterials also ensure significant changes in protein adsorption and biological responses of NPs. Both emulsion droplets and solid polystyrene NPs at the same size were evaluated for IgG adsorption behavior and phagocytic efficiency. The IgG distribution homogeneously around the polystyrene beads was independent with IgG density due to the prevention of IgG lateral mobility caused by solid nanomaterial. Oppositely, IgGs were concentrated in the interface between the emulsion droplets and the cell in case of low IgG densities, while at high IgG densities, there was no appearance of IgG clusters. This can be explained that emulsions allow surface for adsorbed proteins to diffuse and relocate at the interface. Hence, the emulsion formulations can reduce the required protein quantity, or further surface active moieties compared with solid NPs, while achieving the same effect. This suggestion might be valuable in the NP design for diverse pharmaceutical applications. ${ }^{46}$

\section{Protein corona applications Physiological prediction via modeling}

The biological interactions of an NP depend on its physicochemical properties as discussed previously. Some studies have focused on establishing correlations between NP characteristics and biological outcomes for predicting the biological behavior of NPs without explicit experimentation. ${ }^{47}$ Due to the infinite number of NP designs with nature diversity and the complexity of biological systems, it is challenging to set up relationships between NP characteristics and biological responses. A scheme based on correlations between NP physicochemical features and cellular responses, such as cell morphology modifications, cell proliferation, viability and functionality, and reactive oxygen species (ROS) induction, ${ }^{48}$ was suggested for optimizing NP properties to reduce cellular toxicity. ${ }^{49,50}$ Quantitative structure-activity relationship (QSAR) modeling to establish a statistically significant connection between biological activities of NPs and their physicochemical properties was investigated in several studies. ${ }^{51-53}$ The model prediction power for cellular uptake, which was established from 109 manufactured NPs with similar cores decorated by various functional groups, was shown to have a coefficient of determination $\left(R^{2}\right)$ value as high as 0.72 , which means the model was validated and can be used to predict the cellular responses of various nanomaterials as well as promote the tailoring and fabrication of nanomaterials. ${ }^{54}$

The first predictive model based on the protein corona was developed using gold NPs with different sizes and surface alterations. The relative model was built based only on the serum protein corona fingerprint of 129 adsorbed proteins to predict the cell associations of NPs. Applying a bioinformatics-inspired approach, this model reached a high $R^{2}$ value of 0.81 , which is $50 \%$ more precise than previous models that only consider NP physicochemical assessments. Physicochemical property data such as size, zeta potential, and absorbance spectra could not provide sufficient information to establish an acceptably accurate model prediction. However, a model based on the protein corona fingerprint and physicochemical properties of NPs gave a more accurate prediction of Au NP cell associations, with $R^{2}=0.86$. Hence, the protein corona reflects more NP biological details than its physicochemical features. ${ }^{31}$

In the above study, the best prediction model was formed based on 52 independent factors, including various Au NPadsorbed proteins and numerous physicochemical properties. The latter study suggests a more facile way to establish linear and nonlinear predictive models, based mainly on representative adsorbed proteins and zeta potential of $\mathrm{Au}$ NPs with different sizes and surface modifications. The model building factors can be divided into two categories: NP physicochemical properties as synthesized, and with serum (hydrodynamic diameter, total adsorbed protein, binding protein density and so on) and protein corona fingerprints (the type and abundance of adsorbed protein). The highest $R^{2}$ value of the models which were mainly built from the NP physicochemical properties was 0.695 . This result showed that the physicochemical properties of NPs have no relationship to cellular responses. For either linear or nonlinear models, the higher the number of influencing factors, the more accurate the models are established. For example, in cases of non-linear models based on protein corona fingerprints, $R^{2}$ was around 0.62 based on 3 factors, while it was more improved to 0.85 based on 9 factors. Additionally, the prediction accuracy of the nonlinear models was much higher relative to linear models when the same number of factors was used. The most precise model had $R^{2}=0.850$, based on 
11 different adsorbed proteins. More advantageously, the best nonlinear model was established with only 7 factors, including 6 adsorbed proteins and one NP zeta potential, showing higher accuracy value at $R^{2}=0.895 .^{55}$

Another study was also investigated the relationship between cellular interactions with human prostate cancer cells and HeLa cells of diverse liposomes and their physicochemical properties as well as protein corona characteristics. The predictive models were well established, considering cellular viability and uptake in two different cell lines, with $R^{2}$ in the range of $0.79-0.94$. The best variables selected in all correlation models included both physicochemical properties of liposome and descriptors of protein corona fingerprint. ${ }^{56}$ A predictive-validation model of cell association of lipid NPs based on the specifically adsorbed proteins was developed. Interestingly, a small part of the hard corona proteins, consisting of only 8 adsorbed proteins (vitronectin, Apo A1, A2, B, and $\mathrm{C} 2$, and so on), was recognized to include the most important promoters of NP adhesion with HeLa cells among a massive number of possible descriptors ( $\mathrm{N}=436$ proteins). Remarkably, the identification of those importantly adsorbed proteins was found with several high-expression receptors of Hela cell membrane. ${ }^{57}$

Figure 2 shows a scheme for the establishment of predictive model. From the model, biological responses can be predicted without further experiments and highly expressed receptors can be identified from the most influencing proteins for NP design. The abovementioned predictive studies indicate the methodological advantage for the model establishment in which the most important factors are screened first, followed by trying the highly accurate models with small numbers of influencing factors. Reducing the numbers of independent factors simplifies predictive model development, and makes their applicability more practical and economical. Moreover, from the validated model established, the proteins that play important functions correlated with biological responses are identified. Based on these proteins, targeting receptors that are highly expressed on the desired cells can be labeled and applied in NP design. Furthermore, the correlative models between cell association of NPs and both protein corona as well as physicochemical properties of NPs can provide highly accurate information and data for the NP design and make NPs nontoxic.

\section{Modification of NP properties for drug delivery}

The advantages of nanomaterial as drug delivery system are due to the nano sizability that allows NPs to have high drug loading efficiency and to escape from biological barrier for facilitate absorption and biodistribution. The ability of NPs

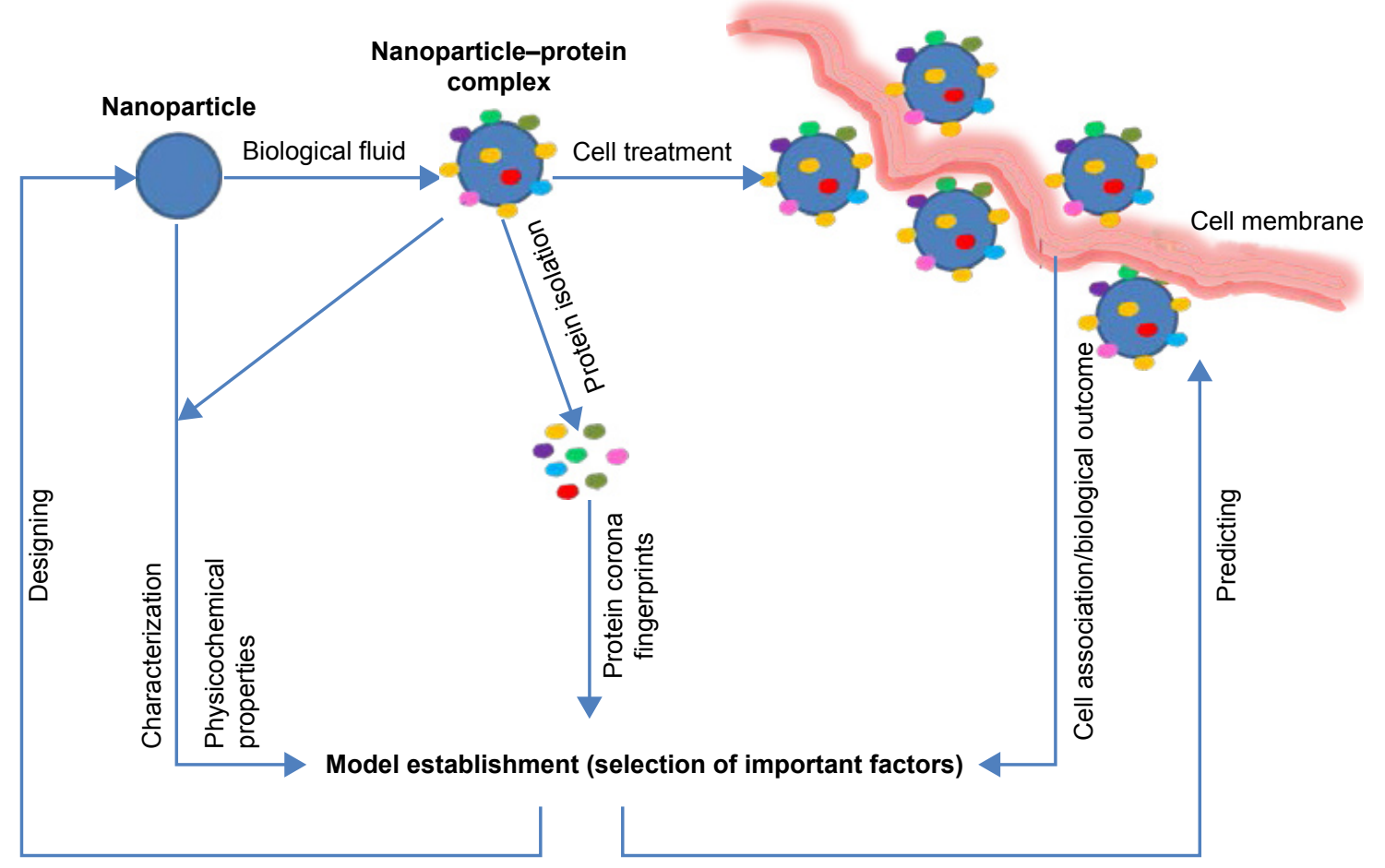

Figure 2 A scheme for the establishment of predictive model.

Note: From the model, biological responses can be predicted without further experiments, and highly expressed receptors can be identified from the most influencing proteins, providing data for NP design.

Abbreviation: NP, nanoparticle. 
to escape from the reticuloendothelial system, to increase half-life, to improve distribution time and accumulation in targeting tissue, and control their toxicity are determining factors for the design and therapeutic efficiency of NPs. To enhance NPs bioavailability and therapeutic response, NP size, nanomaterial, and NP surface are required to be considered for the design and fabrication of NPs. Furthermore, NP surfaces can be modified with diverse functional groups, either inorganic or organic, including proteins with specific activities.

\section{Systemic circulation time of NPs}

The adsorption of protein onto NPs in contact with biological fluid can alter the interactive interface between the NPs and cell membranes, from macrophages and endothelial cells to targeted cells. The binding protein pattern strongly influences phagocytosis and transport of NPs, hence the retention of NPs. If complement factors, fibrinogen, or IgG, called opsonins, are relatively high in protein corona, adsorbed proteins will induce macrophage recognition and engulfment of NPs, leading to the fast removal of NPs out of the body. In contrast, the circulation time is extended in case the protein corona is enriched with albumin or apolipoproteins (Apos), named dysopsonins. ${ }^{37,58-60}$ Therefore, the design of NPs should be aimed to reduce the total adsorption of protein, specifically opsonins, and assist the binding of dysopsonins to prolong NP circulation time in the body as the first key factor for better in vivo performances of NPs.

To enhance the NP bioavailability and therapeutic response, NPs should be initially protected from recruitment of blood proteins. Previous studies used various ligands to pursue NP "stealth effect", for example, peptides designed from human CD47, which prohibits clearance by phagocytes. ${ }^{61}$ Another example is hydrophobin, a fungi secretory substance, which was used to coat NPs in order to reduce protein adsorption. ${ }^{62}$

Another method is furnishing different types of NPs with hydrophilic polymers and surfactants to improve their systemic circulation properties and decrease macrophage recognition. ${ }^{63,64}$ Several well-known hydrophilic polymers include polyethylene glycol (PEG), ${ }^{65}$ poloxamer, ${ }^{25}$ polyvinylpyrrolidone (PVP), and dextran. The hydrophilic properties, the length, and charge from these polymers prevent the interaction of NPs with other biomolecules, including opsonins. ${ }^{66,67}$ Besides, the degree of surface coverage is also an important consideration in design and preparation of NPs to prevent protein adsorption. ${ }^{68,69}$ Among all polymers, PEG is the most commonly used polymer for NP surface modification. NPs surrounded by PEG increased blood circulation time by several orders of magnitude and reduced liver accumulation, depending on the coated PEG molecular weight and surface density. ${ }^{70}$ However, repeated administration of PEG-coated NPs may cause the accelerated blood clearance (ABC) phenomenon as antibodies against PEG increase. ${ }^{71}$

A new finding on the "stealth effect" mechanism by hydrophilic polymers has been elucidated. Previously, this effect is assumed to come from the hydrophilic nature of these polymers, which lowers the quantity of adsorbed proteins. However, PEG-modified NPs showed high and nonspecific cellular uptake when incubated in the media without plasma proteins. This result indicated that the presence of the binding proteins onto hydrophilic polymer layer is essential to reduce NPs internalization into cells. ${ }^{72}$ NPs coated by PVP and PEG increase the systemic circulation time of NPs, compared to the bare ones. Nevertheless, PEG-coated NPs had longer circulations time than PVP-coated NPs. While protein corona of PEG-coated NPs had higher Apo quantities, opsonizing proteins were the major proteins binding to PVPcoated NPs. Therefore, the presence and pattern of binding protein layers strongly affect the "stealth effect" of hydrophilic polymers coated on NPs. ${ }^{14}$ Moreover, "stealth effect" of polymers depends on their individual structure, which is able to induce the selective suppression of the adsorption of opsonins and the favorable binding of "dysopsonin". ${ }^{69,72}$

Another important concept to increase systemic circulation time of NPs in blood is to mask NPs with dysopsonin proteins. By simple incubation, albumin could form a pure protein corona around poly (3-hydroxybutyrate-co-3-hydroxyhexanoate) (PHBHHx) NPs. The albumin corona inhibited plasma protein adsorption and decreased complement activation, resulting in prolonged blood circulation time and reduced cytotoxicity of the biopolymeric PHBHHx NPs. ${ }^{59}$ It was also known that the inclusion of albumin domain into recombinant adenovirus envelope repelled the macrophage recognition and lengthened their retention in the body. ${ }^{73}$

Several apolipoproteins such as ApoA4 and ApoC3 significantly reduced cellular uptake when used for NP precoating. ${ }^{15}$ Apo J, also known as clusterin, has been described to act as a dysopsonin. ${ }^{15,72}$ Apo J, was identified as a major component in the protein corona of both PEGand poly(phosphoester) (PPE)-coated NPs, and induced secondary "stealth effects" in addition to the hydrophilic and neutrally charged properties of the polymers themselves. ${ }^{72}$ Therefore, Apo J might be used as a dysopsonin for decorating NP surface in order to reduce macrophage recognition and lengthen NP circulation time in blood. 
One special case is the well-known opsonin, fibrinogen, which may be used to inhibit cell adhesion at suitable concentrations. In particular, at low-density, fibrinogen forms a monolayer that directly attaches to the NP surface, ${ }^{74}$ leading to high adhesion with platelets and leukocytes. While at high density, the fibrinogen molecules form an extensible multilayer matrix by self-assembly through the interaction between their $\alpha \mathrm{C}$ domains, ${ }^{75,76}$ this dramatically decrease cellular association under both static and flow conditions. ${ }^{74,77}$ These results can suggest a new approach for synthesis and development of biomaterials, specifically in implantation in order to decrease initial thrombogenesis. Thus, using fibrinogen as a surface precoating material in reasonable quantities provides opportunities to protect NPs from endocytosis and prolong circulation time.

\section{Targeting purpose}

NPs with long blood circulation time are a prerequisite for targeted drug delivery, but the accumulation of drug-loaded NPs at the target site is more important than their longer duration of circulation time in the body. Therefore, the surface of conventional NPs has been modified to enhance the stability and lengthen the circulation time of NPs ${ }^{78}$ as well as to control biodistribution. Utilizing proteins adsorbed on NP surfaces alters NP distribution in the body. With protein masks, NP size, shape, and surface properties of NPs are readily modified.

Proteins adsorbed onto NP surfaces increase the NP size..$^{20}$ Specifically, the size of DC-Chol-DOPE/DNA lipoplexes increased from $244 \pm 4 \mathrm{~nm}$ to $741 \pm 1 \mathrm{~nm}$ after incubation with FBS. Hence, the entry pathway of the NPs into cells was switched from clathrin-dependent to caveolae-mediated. ${ }^{79}$ This phenomenon leads to changes in NP cellular internalization, depending on NP size. Moreover, the size of NPs dictates their distribution in the body, as NPs with different size will be accumulated in various organs ${ }^{80}$ Hence, besides surface modification, size should be controlled to achieve distribution and accumulation at target sites. Protein coronas may induce NP aggregation due to the construction of protein bridges ${ }^{81-83}$ Conversely, in several studies, the adsorption of proteins onto NPs also improves NP stability and prevents formation of NP aggregates. ${ }^{84,85}$ Therefore, the protein corona can adjust the average size of NPs and may change the cellular uptake pathway and biodistribution.

NPs are decorated with various active moieties and functional groups to selectively deliver drugs to targeted sites in the body. Several targeting functional biomolecules include transferrin, insulin, folic acid, apo A-1, and apo E, which are commonly used in designing cancer-targeting drug delivery systems. Other small molecules such as anhydride, amine, hydroxyl, carboxyl, thiol, and epoxy could be used to alter NP delivery, as they directed NPs to high cellular association with endothelial cells, pancreatic cancer cells, or activated human macrophages. ${ }^{86}$ Some apolipoproteins, Apo E, ApoA1, and ApoB-100, could functionalize NPs to target nervous system. ${ }^{87,88}$ Covalently binding Apo E NPs are clearly taken up by the brain endothelial cells while PEGylated NPs did not appear in brain tissue $30 \mathrm{~min}$ postadministration. ${ }^{87}$

Surface modification of NPs by various functional proteins before an administration can be done simply by incubation ${ }^{59,89}$ or by covalent conjugation. ${ }^{37} \mathrm{~A}$ well-known example of this method is nanoparticle albumin-bound (nab) technology, in which albumin is attached to the NP surface to successfully target tumors and reduce toxicity. Abraxane, a prominently marketed anticancer product containing paclitaxel, was fabricated using the nab technique. BSA and human IgG as functional groups were conjugated to polystyrene NP surfaces. ${ }^{37}$ Artificially decorating NPs with Apo $\mathrm{H}$ increased their cellular uptake in HeLa human cancer cells. ${ }^{15}$ Albumin and Apo E coating of gold NPs not only increases blood circulation time compared to citrate-stabilized gold NPs, but also affects NP biodistribution, shifting NP accumulation from the liver to enhanced amounts in the spleen. Importantly, albumin coating of NP surfaces significantly increased NP delivery into the nervous system and lung. These results could be applied to tailor nanomaterials that target the brain and the lung. ${ }^{90}$

Though in some reported cases, the targeting properties of NPs may be hindered by protein adsorption, preventing the interaction of functional ligands with corresponding cell receptors. ${ }^{91}$ For example, transferrin-modified NPs lose their targeting effect due to surface adsorption of biomolecules. ${ }^{92}$ Additionally, the masking efficiency of proteins onto NPs can be relatively reduced by the presence of competitive proteins that have the same receptors. The cellular uptake of BSA preadsorbed polystyrene NPs was reduced by nearly $70 \%$ in MEM supplemented with $10 \%$ BSA compared to MEM without BSA addition. Hence, in order to reach to the targeted cell receptors, the active groups, specifically biomolecules which bind to NP surface, must have higher affinity with receptor binding region than nonspecific proteins. ${ }^{9}$

A more advantageous method for targeting purpose is tailoring the NP properties that are able to selectively adsorb endogenous proteins, which leads the NP to desired cells..$^{93}$ Figure 3 shows a new targeting strategy for NP design to cells 

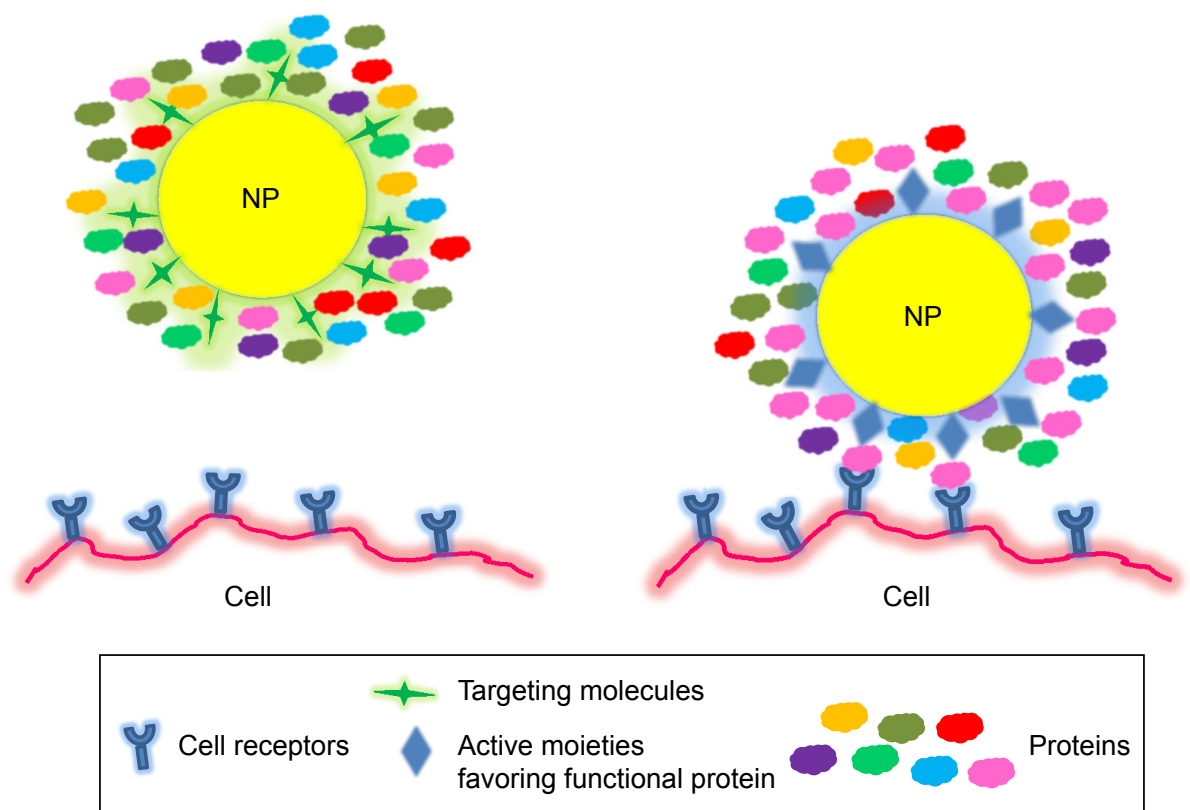

Figure $3 \mathrm{New}$ targeting strategy for NP design to cells using different surface-modified ligands.

Notes: Left: Adsorbed proteins hinder targeting ligands conjugated on the NP surface. Right: Surface-modified NPs favor functional proteins, which direct NPs to the desired cell.

Abbreviation: NP, nanoparticle.

using different surface-modified ligands. Adsorbed proteins may hinder targeting ligands conjugated on the NP surface, but some surface-modified NPs favoring functional proteins can direct NPs to the desired target cells. Modification of NP characteristics, especially their surfaces, will turn the protein corona of NPs by altering interaction between NP and cell membrane receptors, hence governing cellular uptake and responses of NPs.

The main strategy in novel NP targeting design includes three steps. First, finding particular proteins that can bind to NPs may be further enhanced with cumulative activity proteins to bring NPs to desired locations. Second, identifying NP-specific characteristics that strengthen the recruitment of the desired proteins and accomplish the formation of a suitable protein corona with or without modifying the natural protein structure so as to pursue the intended targeting responses. Third, considering the influence of protein exchange over time on biological and therapeutic outcomes. ${ }^{94}$

For example, when incubating with 50\% plasma, liposomes prepared from 1,2-dioleoyl-3-trimethylammonium propane were enriched with vitronectin, which is a major ligand for the vitronectin receptor in several tumor cell lines. Protein-NP complex showed higher cellular uptake in metastatic MDA-MB-435 cells than bare NPs. ${ }^{95}$ Retinol binding protein 4 (RBP) was favorably adsorbed to retinol-conjugated polyetherimide NPs. RBP was found to bind retinol and direct the retinol-conjugated polyetherimine ( $\mathrm{RcP})$ NPs to hepatic stellate cells. ${ }^{96}$

After exposing to plasma, polysorbate-coated NPs were enriched with Apo E or Apo AI, and highly distributed in brain endothelium, which was also observed in the case of covalent Apo E binding NPs. ${ }^{88,97}$ Polybutyl cyanoacrylate (PBC) NPs and polymethyl methacrylate (PMMA) NPs covered by polysorbates could also selectively recruit apolipoproteins binding to their surfaces for brain-targeting applications. $^{98-100}$

Coating NPs with particular proteins can help determine the adsorbed protein patterns onto NPs. Preformed NPs with HSA decrease the recruitment of coagulation factors, especially fibrinogen, while $\gamma$ globulin layer around NPs enhanced the relative quantities of complement factors and immunoglobulins. However, the adsorbed proteins recruited from $55 \%$ plasma screened the effect of $\gamma$ globulin layer, which was indicated by lower cellular uptake on RAW 264.7 cells than the ones that interacted with 10\% FBS-containing media. This can be explained by the difference of protein quantity between 55\% plasma solution and 10\% FBS. Therefore, protein-functionalized NPs should be exposed to media for a shorter and more reasonable duration in which the efficiency of NP ligands still retain and express their effect before being affected by the adsorption of other media proteins. ${ }^{101}$ When NPs come into contact with biological fluid, the evolution of proteins is essential to be considered as the difference in the 
adsorbed proteins' compositions, their relative abundances, and total binding proteins strongly affect cellular uptake and therapeutic responses. ${ }^{101}$

Small libraries of synthetic polymeric NPs mainly fabricated with poly(N-isopropylacrylamide) (NIPAm) and other functional monomers at different ratios could be screened for control of protein adsorption. NP compositions were successfully optimized for binding affinity and selectivity toward desired proteins in complicated biological environments. Hence, these NIPAm NPs can be applied in protein purification, sequestration of lipid-bound toxins, and targeted drug delivery systems by turning the protein corona through NP tailoring. ${ }^{43}$

\section{Toxicity reduction}

The interaction with NP has a strong impact on cellular behaviors and may cause cell death through a disruption of the integrity of plasma membrane, mitochondrial impairment, and nucleus damage. NPs could provoke inflammatory and oxidative stress, which finally results in cell death. The formation of protein corona alters the immune response of NPs. ${ }^{102}$ The protective effect of adsorbed protein against cell damage induced by the bare NPs was investigated in numerous studies, ${ }^{35,103,104}$ possibly because protein covered the NP surface and made NPs more biocompatible to the human body.

A BSA adsorbed layer reduced the cell cytotoxicity of naked PHBHHx NPs, obviously with high NP treatment of three different cell lines: A549, HepG2, and L929 cells. ${ }^{59}$ The masking effects of several types of human blood proteins, specifically, bovine fibrinogen (BFG), BSA, transferrin (Tf), and $\gamma$ globulin (Ig), on single wall carbon nanotubes (SWCNTs) decreased toxicity compared to bare SWCNTs in human acute monocytic leukemia cells (THP-1) and human umbilical vein endothelial cells (HUVECs). The impacts of these SWCNT-protein complexes had a similar decreasing order to their protein affinities: $\mathrm{BFG}>\mathrm{Ig}>\mathrm{Tf}>\mathrm{BSA}$ for THP-1 cells. ${ }^{105}$ Using BSA for coating of $\mathrm{ZnO}$ NPs, prepared at $4^{\circ} \mathrm{C}$, reduced the toxicity of uncoated $\mathrm{ZnO}$ NPs on $\mathrm{CHO}$ cells and inhibited $\mathrm{ZnO}$ NPs from inducing ROS generation. However, the change of BSA structure when BSA coating happened at an elevated $20^{\circ} \mathrm{C}$ lessened the toxicity reduction effect of BSA for ZnO NPs. ${ }^{106}$ Hence, surface modification procedure by adsorbing proteins needs to be carefully considered and optimized to obtain the best therapeutic effects. Adsorbed proteins covering positively charged polystyrene compensated the NP surface charges and were retained when NPs made contact with cell (lung epithelial A549 cells and human brain astrocytoma $1321 N 1$ cells) membranes, and only degraded when trafficked to lysosomes. In this case, the protein corona could mask the polystyrene NPs by preventing direct contact between bare NPs and cell membranes, thereby inhibiting cell death caused by positively charged NPs. ${ }^{35}$

\section{Future perspectives}

It is not bare NPs, but protein-adsorbed NPs that represent the true identity and therapeutic responses of NPs when they enter into the body. Therefore, a thorough knowledge and understanding of protein-NP complex and its interactions is important to predict and govern the in vivo fate of NPs after administration, including biodistribution, bioavailability responses, and toxicity. The correlation models for biological and therapeutic outcomes based on protein corona patterns of NPs are validated with considerably higher accuracy than previous models whose input factors include mainly NP physicochemical properties. Hence, bioavailability of an NP product would be able to be precisely measured without in vivo tests on humans. From these correlative models, nanomaterials can be synthesized for determination of the required binding protein motifs for novel drug delivery carriers or diagnostic devices. ${ }^{107}$ Protein corona patterns, especially proteins which have powerful impacts on cellular uptake and biological responses, can be used to identify the overexpressed receptors on targeting cells as novel pharmacological approaches are discovered. ${ }^{108}$ Moreover, the presence of different types of adsorbed proteins on NPs provides details about the biological fluids and blood components which NPs go through in the body. Thus, these information can be used for examining and diagnosing the physiological changes in our body related to protein modulation and structural deformation, such as in tumorigenesis and disease development. ${ }^{93}$

To enhance the precise prediction of in vivo biological outcomes and practical applications of protein corona in pharmaceutical sciences, initially a full assessment of NP-protein interaction in stimulated biomimetic administration conditions must be done. ${ }^{109}$ Specifically, media exposure factors including proteins, fluidic shear stress, and also degradable enzymes should be carefully set up. Besides, the invention of new pharmaceutical technologies such as tumor-on-a-chip models and biomimetic microfluidic systems allow for more deeper evaluation of NP behaviors. ${ }^{110}$

Notably, different types of diseases can cause decoration of the NP protein. ${ }^{11}$ The changes in plasma protein concentrations, protein structures, and body temperature mediated by different disease states and medical conditions, 
extensively including breast cancer, diabetes, hypercholesterolemia, rheumatism, fauvism, smoking, hemodialysis, thalassemia, hemophilia A and B, pregnancy, common cold, and hypofibrinogenemia, alter NP-adsorbed protein pattern This new finding also suggests new avenues for creating and designing safe and highly efficient NPs for personalized drug delivery system. ${ }^{112}$

NP-protein interaction offers potential way to design nanoparticulate drug delivery systems in which controlling protein and protein corona can mask NP surface and perform desirable biological functions. ${ }^{113}$ The "dysopsonins" such as BSA and Apo J offer a simple way to create and enrich the "stealth effect" for NPs, in which NPs are just mixed and controlled with human plasma or a specific protein component before administration, ${ }^{69,72}$ instead of undergoing complicated preparation procedures of NPs. Protein structural modification and approachability of adsorbed proteins should be carefully considered in the tailoring of preformed protein NPs for effective therapeutic activities mediated through binding with relevant cell receptors. ${ }^{114}$ Protein directionality decides the flexibility and availability of optimal binding sites and protein function. Therefore, the directionality of the protein as well as the degree of conjugation/adsorption is essential for NP construction and design in drug delivery. The orientation of the protein component and the level of affected protein structures/dysfunction depend on the interactive region of proteins. Cautious consideration about surface topography and chemistry as well as detailed structural protein information will lead to greater managing of the orientation and properties of decorated proteins on NP surface. ${ }^{115}$ Materials or nanomaterials which poorly adsorb protein will lead to the positive effect of prolonged circulation time but also the negative effect of low cellular uptake, in the case of hydrophilic polymers and vice versa. ${ }^{24,72}$ Hence, the balance and harmonization between the complicated effect of diverse binding proteins on biological effectiveness and escape of phagocytosis is a challenging task in tailoring and designing NPs.

In summary, the in-depth understanding and knowledge of protein corona opens up a new method for NP design in which the creative production of novel nanomaterials would strategically begin with the identification of essential fingerprint pattern and conformation of protein corona to achieve the desired biological and therapeutic outomes. ${ }^{116}$

\section{Acknowledgment}

This research was supported by a grant (16173MFDS542) from Ministry of Food and Drug Safety in 2016, Republic of Korea.

\section{Disclosure}

The authors report no conflicts of interest in this work.

\section{References}

1. Corbo C, Molinaro R, Parodi A, Toledano Furman NE, Salvatore F, Tasciotti E. The impact of nanoparticle protein corona on cytotoxicity, immunotoxicity and target drug delivery. Nanomedicine. 2016;11(1): 81-100.

2. Vroman L, Adams A, Fischer GC, Munoz PC. Interaction of high molecular weight kininogen, factor XII, and fibrinogen in plasma at interfaces. Blood. 1980;55(1):156-159.

3. Mahmoudi M, Sheibani S, Milani AS, et al. Crucial role of the protein corona for the specific targeting of nanoparticles. Nanomedicine. 2015; 10(2):215-226.

4. Lundqvist M, Stigler J, Elia G, Lynch I, Cedervall T, Dawson KA. Nanoparticle size and surface properties determine the protein corona with possible implications for biological impacts. Proc Natl Acad Sci US A. 2008;105(38):14265-14270.

5. Sacchetti C, Motamedchaboki K, Magrini A, et al. Surface polyethylene glycol conformation influences the protein corona of polyethylene glycol-modified single-walled carbon nanotubes: potential implications on biological performance. ACS Nano. 2013;7(3):1974-1989.

6. Lynch I, Dawson KA. Protein-nanoparticle interactions. Nano Today. 2008;3(1):40-47.

7. Koegler P, Clayton A, Thissen H, Santos GN, Kingshott P. The influence of nanostructured materials on biointerfacial interactions. Adv Drug Deliv Rev. 2012;64(15):1820-1839.

8. Hühn D, Kantner K, Geidel C, et al. Polymer-coated nanoparticles interacting with proteins and cells: focusing on the sign of the net charge. ACS Nano. 2013;7(4):3253-3263.

9. Fleischer CC, Payne CK. Nanoparticle-cell interactions: molecular structure of the protein corona and cellular outcomes. Acc Chem Res. 2014; 47(8):2651-2659.

10. Fleischer CC, Kumar U, Payne CK. Cellular binding of anionic nanoparticles is inhibited by serum proteins independent of nanoparticle composition. Biomater Sci. 2013;1(9):975-982.

11. Goy-López S, Juárez J, Alatorre-Meda M, et al. Physicochemical characteristics of protein-NP bioconjugates: the role of particle curvature and solution conditions on human serum albumin conformation and fibrillogenesis inhibition. Langmuir. 2012;28(24):9113-9126.

12. Orts-Gil G, Natte K, Thiermann R, et al. On the role of surface composition and curvature on biointerface formation and colloidal stability of nanoparticles in a protein-rich model system. Colloids Surf B Biointerfaces. 2013;108:110-119.

13. Staufenbiel S, Merino M, Li W, et al. Surface characterization and protein interaction of a series of model poly[acrylonitrile-co-(N-vinyl pyrrolidone)] nanocarriers for drug targeting. Int J Pharm. 2015;485(1-2):87-96.

14. Gaucher G, Asahina K, Wang J, Leroux JC. Effect of poly (N-vinylpyrrolidone)-block-poly (D, L-lactide) as coating agent on the opsonization, phagocytosis, and pharmacokinetics of biodegradable nanoparticles. Biomacromolecules. 2009;10(2):408-416.

15. Ritz S, Schöttler S, Kotman N, et al. Protein corona of nanoparticles: distinct proteins regulate the cellular uptake. Biomacromolecules. 2015;16(4):1311-1321.

16. Kang B, Okwieka P, Schöttler S, et al. Tailoring the stealth properties of biocompatible polysaccharide nanocontainers. Biomaterials. 2015;49: 125-134.

17. Lundqvist M, Stigler J, Cedervall T, et al. The evolution of the protein corona around nanoparticles: a test study. ACS Nano. 2011;5(9): 7503-7509.

18. Maiorano G, Sabella S, Sorce B, et al. Effects of cell culture media on the dynamic formation of protein-nanoparticle complexes and influence on the cellular response. ACS Nano. 2010;4(12):7481-7491.

19. Martel J, Young D, Young A, et al. Comprehensive proteomic analysis of mineral nanoparticles derived from human body fluids and analyzed by liquid chromatography-tandem mass spectrometry. Anal Biochem. 2011;418(1):111-125. 
20. Dobrovolskaia MA, Patri AK, Zheng J, et al. Interaction of colloidal gold nanoparticles with human blood: effects on particle size and analysis of plasma protein binding profiles. Nanomedicine. 2009;5(2): 106-117.

21. Joseph D, Sachar S, Kishore N, Chandra S. Mechanistic insights into the interactions of magnetic nanoparticles with bovine serum albumin in presence of surfactants. Colloids Surf B Biointerfaces. 2015; 135:596-603.

22. Palchetti S, Colapicchioni V, Digiacomo L, et al. The protein corona of circulating PEGylated liposomes. Biochim Biophys Acta. 2016;1858(2): 189-196.

23. Tenzer S, Docter D, Kuharev J, et al. Rapid formation of plasma protein corona critically affects nanoparticle pathophysiology. Nat Nanotechnol. 2013;8(10):772-781.

24. Sanchez-Moreno P, Buzon P, Boulaiz H, et al. Balancing the effect of corona on therapeutic efficacy and macrophage uptake of lipid nanocapsules. Biomaterials. 2015;61:266-278.

25. Shubhra QT, Toth J, Gyenis J, Feczko T. Surface modification of HSA containing magnetic PLGA nanoparticles by poloxamer to decrease plasma protein adsorption. Colloids Surf B Biointerfaces. 2014;122: 529-536.

26. Lindman S, Lynch I, Thulin E, Nilsson H, Dawson KA, Linse S. Systematic investigation of the thermodynamics of HSA adsorption to N-iso-propylacrylamide/N-tert-butylacrylamide copolymer nanoparticles. Effects of particle size and hydrophobicity. Nano Lett. 2007;7(4):914-920.

27. Monopoli MP, Walczyk D, Campbell A, et al. Physical - chemical aspects of protein corona: relevance to in vitro and in vivo biological impacts of nanoparticles. J Am Chem Soc. 2011;133(8):2525-2534.

28. Diederichs JE. Plasma protein adsorption patterns on liposomes: establishment of analytical procedure. Electrophoresis. 1996;17(3): 607-611.

29. Thode K, Lück M, Semmler W, Müller RH, Kresse M. Determination of plasma protein adsorption on magnetic iron oxides: sample preparation. Pharm Res. 1997;14(7):905-910.

30. Cedervall T, Lynch I, Lindman S, et al. Understanding the nanoparticle-protein corona using methods to quantify exchange rates and affinities of proteins for nanoparticles. Proc Natl Acad Sci US A. 2007; 104(7):2050-2055.

31. Walkey CD, Olsen JB, Song F, et al. Protein corona fingerprinting predicts the cellular interaction of gold and silver nanoparticles. ACS Nano. 2014;8(3):2439-2455.

32. Winzen S, Schoettler S, Baier G, et al. Complementary analysis of the hard and soft protein corona: sample preparation critically effects corona composition. Nanoscale. 2015;7(7):2992-3001.

33. Lesniak A, Fenaroli F, Monopoli MP, Åberg C, Dawson KA, Salvati A. Effects of the presence or absence of a protein corona on silica nanoparticle uptake and impact on cells. ACS Nano. 2012;6(7):5845-5857.

34. Grafe C, Weidner A, Luhe MV, et al. Intentional formation of a protein corona on nanoparticles: serum concentration affects protein corona mass, surface charge, and nanoparticle-cell interaction. Int J Biochem Cell Biol. 2016;75:196-202.

35. Wang F, Yu L, Monopoli MP, et al. The biomolecular corona is retained during nanoparticle uptake and protects the cells from the damage induced by cationic nanoparticles until degraded in the lysosomes. Nanomedicine. 2013;9(8):1159-1168.

36. Yallapu MM, Chauhan N, Othman SF, et al. Implications of protein corona on physico-chemical and biological properties of magnetic nanoparticles. Biomaterials. 2015;46:1-12.

37. Thiele L, Diederichs JE, Reszka R, Merkle HP, Walter E. Competitive adsorption of serum proteins at microparticles affects phagocytosis by dendritic cells. Biomaterials. 2003;24(8):1409-1418.

38. Behzadi S, Serpooshan V, Sakhtianchi R, et al. Protein corona change the drug release profile of nanocarriers: the "overlooked" factor at the nanobio interface. Colloids Surf B Biointerfaces. 2014;123:143-149.

39. Kang T, Park C, Choi JS, Cui JH, Lee BJ. Effects of shear stress on the cellular distribution of polystyrene nanoparticles in a biomimetic microfluidic system. J Drug Deliv Sci Technol. 2016;31:130-136.
40. Marieb EN, Hoehn K. The Cardiovascular System: Blood Vessels. 9th ed. Upper Saddle River, NJ: Pearson Education, Inc; 2013.

41. Bhogale A, Patel N, Mariam J, Dongre P, Miotello A, Kothari D. Comprehensive studies on the interaction of copper nanoparticles with bovine serum albumin using various spectroscopies. Colloids Surf B Biointerfaces. 2014;113:276-284.

42. Mahmoudi M, Abdelmonem AM, Behzadi S, et al. Temperature: the "ignored" factor at the NanoBio interface. ACS Nano. 2013;7(8): 6555-6562.

43. O'Brien J, Shea KJ. Tuning the protein corona of hydrogel nanoparticles: the synthesis of abiotic protein and peptide affinity reagents. Acc Chem Res. 2016;49(6):1200-1210.

44. Capriotti AL, Caracciolo G, Caruso G, et al. Differential analysis of "protein corona" profile adsorbed onto different nonviral gene delivery systems. Anal Biochem. 2011;419(2):180-189.

45. Mahmoudi M, Lynch I, Ejtehadi MR, Monopoli MP, Bombelli FB, Laurent S. Protein-nanoparticle interactions: opportunities and challenges. Chem Rev. 2011;111(9):5610-5637.

46. M'Barek KB, Molino D, Quignard S, et al. Phagocytosis of immunoglobulin-coated emulsion droplets. Biomaterials. 2015;51:270-277.

47. Shaw SY, Westly EC, Pittet MJ, Subramanian A, Schreiber SL, Weissleder R. Perturbational profiling of nanomaterial biologic activity. Proc Natl Acad Sci U S A. 2008;105(21):7387-7392.

48. Soenen SJ, Himmelreich U, Nuytten N, De Cuyper M. Cytotoxic effects of iron oxide nanoparticles and implications for safety in cell labelling. Biomaterials. 2011;32(1):195-205.

49. Zhang H, Ji Z, Xia T, et al. Use of metal oxide nanoparticle band gap to develop a predictive paradigm for oxidative stress and acute pulmonary inflammation. ACS Nano. 2012;6(5):4349-4368.

50. Soenen SJ, Rivera-Gil P, Montenegro JM, Parak WJ, De Smedt SC, Braeckmans K. Cellular toxicity of inorganic nanoparticles: common aspects and guidelines for improved nanotoxicity evaluation. Nano Today. 2011;6(5):446-465.

51. Liu R, Rallo R, George S, et al. Classification NanoSAR development for cytotoxicity of metal oxide nanoparticles. Small. 2011;7(8): 1118-1126.

52. Puzyn T, Leszczynska D, Leszczynski J. Toward the development of "nano-QSARs": Advances and challenges. Small. 2009;5(22): 2494-2509.

53. Puzyn T, Rasulev B, Gajewicz A, et al. Using nano-QSAR to predict the cytotoxicity of metal oxide nanoparticles. Nature Nanotechnol. 2011;6(3):175-178.

54. Fourches D, Pu D, Tassa C, et al. Quantitative nanostructure - activity relationship modeling. ACS Nano. 2010;4(10):5703-5712.

55. Liu R, Jiang W, Walkey CD, Chan WC, Cohen Y. Prediction of nanoparticles-cell association based on corona proteins and physicochemical properties. Nanoscale. 2015;7(21):9664-9675.

56. Bigdeli A, Palchetti S, Pozzi D, et al. Exploring cellular interactions of liposomes using protein corona fingerprints and physicochemical properties. ACS Nano. 2016;10(3):3723-3737.

57. Palchetti S, Digiacomo L, Pozzi D, et al. Nanoparticles-cell association predicted by protein corona fingerprints. Nanoscale. 2016;8(25): $12755-12763$.

58. Ogawara K, Furumoto K, Nagayama S, et al. Pre-coating with serum albumin reduces receptor-mediated hepatic disposition of polystyrene nanosphere: implications for rational design of nanoparticles. J Control Release. 2004;100(3):451-455.

59. Peng Q, Zhang S, Yang Q, et al. Preformed albumin corona, a protective coating for nanoparticles based drug delivery system. Biomaterials. 2013;34(33):8521-8530.

60. Göppert T, Müller R. Adsorption kinetics of plasma proteins on solid lipid nanoparticles for drug targeting. Int J Pharm. 2005;302(1):172-186.

61. Rodriguez PL, Harada T, Christian DA, Pantano DA, Tsai RK, Discher DE. Minimal "Self" peptides that inhibit phagocytic clearance and enhance delivery of nanoparticles. Science. 2013;339(6122):971-975.

62. Grunér M, Kauscher U, Linder M, Monopoli M. An environmental route of exposure affects the formation of nanoparticle coronas in blood plasma. J Proteomics. 2016;137:52-58. 
63. Müller J, Bauer KN, Prozeller D, et al. Coating nanoparticles with tunable surfactants facilitates control over the protein corona. Biomaterials. 2017;115:1-8.

64. Aggarwal P, Hall JB, McLeland CB, Dobrovolskaia MA, McNeil SE. Nanoparticle interaction with plasma proteins as it relates to particle biodistribution, biocompatibility and therapeutic efficacy. Adv Drug Deliv Rev. 2009;61(6):428-437.

65. Wang Q, Sun Y, Zhang Z, Duan Y. Targeted polymeric therapeutic nanoparticles: Design and interactions with hepatocellular carcinoma. Biomaterials. 2015;56:229-240.

66. Owens DE, Peppas NA. Opsonization, biodistribution, and pharmacokinetics of polymeric nanoparticles. Int J Pharm. 2006;307(1):93-102.

67. Lemarchand C, Gref R, Lesieur S, et al. Physico-chemical characterization of polysaccharide-coated nanoparticles. J Control Release. 2005; 108(1):97-111.

68. Szleifer I, Carignano M. Tethered polymer layers: phase transitions and reduction of protein adsorption. Macromol Rapid Commun. 2000; 21(8):423-448.

69. Natte K, Friedrich JF, Wohlrab S, et al. Impact of polymer shell on the formation and time evolution of nanoparticle - protein corona. Colloids Surf B Biointerfaces. 2013;104:213-220.

70. Gref R, Domb A, Quellec P, et al. The controlled intravenous delivery of drugs using PEG-coated sterically stabilized nanospheres. Adv Drug Deliv Rev. 2012;64:316-326.

71. Knop K, Hoogenboom R, Fischer D, Schubert US. Poly (ethylene glycol) in drug delivery: pros and cons as well as potential alternatives. Angew Chem Int Ed Engl. 2010;49(36):6288-6308.

72. Schöttler S, Becker G, Winzen S, et al. Protein adsorption is required for stealth effect of poly (ethylene glycol)-and poly (phosphoester)-coated nanocarriers. Nat Nanotechnol. 2016;11(4):372-377.

73. Rojas LA, Condezo GN, Moreno R, et al. Albumin-binding adenoviruses circumvent pre-existing neutralizing antibodies upon systemic delivery. J Control Release. 2016;237:78-88.

74. Yermolenko IS, Fuhrmann A, Magonov SN, et al. Origin of the nonadhesive properties of fibrinogen matrices probed by force spectroscopy. Langmuir. 2010;26(22):17269-17277.

75. Yermolenko IS, Gorkun OV, Fuhrmann A, et al. The assembly of nonadhesive fibrinogen matrices depends on the $\alpha \mathrm{C}$ regions of the fibrinogen molecule. J Biol Chem. 2012;287(50):41979-41990.

76. Safiullin R, Christenson W, Owaynat H, et al. Fibrinogen matrix deposited on the surface of biomaterials acts as a natural anti-adhesive coating. Biomaterials. 2015;67:151-159.

77. Lishko VK, Burke T, Ugarova T. Antiadhesive effect of fibrinogen: a safeguard for thrombus stability. Blood. 2007;109(4):1541-1549.

78. Storm G, Belliot SO, Daemen T, Lasic DD. Surface modification of nanoparticles to oppose uptake by the mononuclear phagocyte system. Adv Drug Deliv Rev. 1995;17(1):31-48.

79. Caracciolo G, Callipo L, De Sanctis SC, Cavaliere C, Pozzi D, Laganà A. Surface adsorption of protein corona controls the cell internalization mechanism of DC-Chol-DOPE/DNA lipoplexes in serum. Biochim Biophys Acta. 2010;1798(3):536-543.

80. Gaumet M, Vargas A, Gurny R, Delie F. Nanoparticles for drug delivery: the need for precision in reporting particle size parameters. Eur $J$ Pharm Biopharm. 2008;69(1):1-9.

81. Deng ZJ, Liang M, Toth I, Monteiro MJ, Minchin RF. Molecular interaction of poly (acrylic acid) gold nanoparticles with human fibrinogen. ACS Nano. 2012;6(10):8962-8969.

82. Zhu J, Sun Z, Li JJ, Zhao JW. Bovine serum albumins (BSA) induced aggregation and separation of gold colloid nanoparticles. J Nanosci Nanotechnol. 2012;12(3):2206-2211.

83. Kendall M, Ding P, Kendall K. Particle and nanoparticle interactions with fibrinogen: the importance of aggregation in nanotoxicology. Nanotoxicology. 2011;5(1):55-65.

84. Dominguez-Medina S, Blankenburg J, Olson J, Landes CF, Link S. Adsorption of a protein monolayer via hydrophobic interactions prevents nanoparticle aggregation under harsh environmental conditions. ACS Sustain Chem Eng. 2013;1(7):833-842.
85. Wells MA, Abid A, Kennedy IM, Barakat AI. Serum proteins prevent aggregation of $\mathrm{Fe} 2 \mathrm{O} 3$ and $\mathrm{ZnO}$ nanoparticles. Nanotoxicology. 2012;6(8):837-846.

86. Weissleder R, Kelly K, Sun EY, Shtatland T, Josephson L. Cellspecific targeting of nanoparticles by multivalent attachment of small molecules. Nat Biotechnol. 2005;23(11):1418-1423.

87. Zensi A, Begley D, Pontikis C, et al. Albumin nanoparticles targeted with Apo E enter the CNS by transcytosis and are delivered to neurones. J Control Release. 2009;137(1):78-86.

88. Kreuter J, Hekmatara T, Dreis S, Vogel T, Gelperina S, Langer K. Covalent attachment of apolipoprotein AI and apolipoprotein B-100 to albumin nanoparticles enables drug transport into the brain. J Control Release. 2007;118(1):54-58.

89. Venerando R, Miotto G, Magro M, et al. Magnetic nanoparticles with covalently bound self-assembled protein corona for advanced biomedical applications. J Phys Chem C. 2013;117(39):20320-20331.

90. Schäffler M, Sousa F, Wenk A, et al. Blood protein coating of gold nanoparticles as potential tool for organ targeting. Biomaterials. 2014; 35(10):3455-3466.

91. Mirshafiee V, Mahmoudi M, Lou K, Cheng J, Kraft ML. Protein corona significantly reduces active targeting yield. Chem Commun. 2013;49(25):2557-2559.

92. Salvati A, Pitek AS, Monopoli MP, et al. Transferrin-functionalized nanoparticles lose their targeting capabilities when a biomolecule corona adsorbs on the surface. Nat Nanotechnol. 2013;8(2):137-143.

93. Caracciolo G. Liposome-protein corona in a physiological environment: challenges and opportunities for targeted delivery of nanomedicines. Nanomedicine. 2015;11(3):543-557.

94. Rahman M, Laurent S, Tawil N, Yahia L, Mahmoudi M. ProteinNanoparticle Interactions. Vol 15. 1st ed. Berlin, Germany: SpringerVerlag; 2013.

95. Caracciolo G, Pozzi D, Capriotti A, et al. Cancer cell targeting of lipid gene vectors by protein corona. Nanotechnology. 2012;3:354-357.

96. Zhang Z, Wang C, Zha Y, et al. Corona-directed nucleic acid delivery into hepatic stellate cells for liver fibrosis therapy. ACS Nano. 2015;9(3):2405-2419.

97. Petri B, Bootz A, Khalansky A, et al. Chemotherapy of brain tumour using doxorubicin bound to surfactant-coated poly (butyl cyanoacrylate) nanoparticles: revisiting the role of surfactants. J Control Release. 2007;117(1):51-58.

98. Borchard G, Audus KL, Shi F, Kreuter J. Uptake of surfactant-coated poly (methyl methacrylate)-nanoparticles by bovine brain microvessel endothelial cell monolayers. Int J Pharm. 1994;110(1):29-35.

99. Gulyaev AE, Gelperina SE, Skidan IN, Antropov AS, Kivman GY, Kreuter J. Significant transport of doxorubicin into the brain with polysorbate 80-coated nanoparticles. Pharm Res. 1999;16(10): 1564-1569.

100. Kreuter J, Petrov V, Kharkevich D, Alyautdin R. Influence of the type of surfactant on the analgesic effects induced by the peptide dalargin after its delivery across the blood-brain barrier using surfactant-coated nanoparticles. J Control Release. 1997;49(1):81-87.

101. Mirshafiee V, Kim R, Park S, Mahmoudi M, Kraft ML. Impact of protein pre-coating on the protein corona composition and nanoparticle cellular uptake. Biomaterials. 2016;75:295-304.

102. Lee YK, Choi EJ, Webster TJ, Kim SH, Khang D. Effect of the protein corona on nanoparticles for modulating cytotoxicity and immunotoxicity. Int J Nanomedicine. 2015;10:97.

103. Clift MJ, Bhattacharjee S, Brown DM, Stone V. The effects of serum on the toxicity of manufactured nanoparticles. Toxicol Lett. 2010;198(3):358-365.

104. Tedja R, Lim M, Amal R, Marquis C. Effects of serum adsorption on cellular uptake profile and consequent impact of titanium dioxide nanoparticles on human lung cell lines. ACS Nano. 2012;6(5): 4083-4093.

105. Ge C, Du J, Zhao L, et al. Binding of blood proteins to carbon nanotubes reduces cytotoxicity. Proc Nat Acad Sci. 2011;108(41): $16968-16973$. 
106. Žūkienė R, Snitka V. Zinc oxide nanoparticle and bovine serum albumin interaction and nanoparticles influence on cytotoxicity in vitro. Colloids Surf B Biointerfaces. 2015;135:316-323.

107. Miotto G, Magro M, Terzo M, et al. Protein corona as a proteome fingerprint: the example of hidden biomarkers for cow mastitis. Colloids Surf B Biointerfaces. 2016;140:40-49.

108. Arvizo RR, Giri K, Moyano D, et al. Identifying new therapeutic targets via modulation of protein corona formation by engineered nanoparticles. PloS One. 2012;7(3):e33650.

109. Mirshafiee V, Kim R, Mahmoudi M, Kraft ML. The importance of selecting a proper biological milieu for protein corona analysis in vitro: human plasma versus human serum. Int J Biochem Cell Biol. 2016;75:188-195.

110. Maiolo D, Del Pino P, Metrangolo P, Parak WJ, Baldelli Bombelli F. Nanomedicine delivery: does protein corona route to the target or off road? Nanomedicine. 2015;10(21):3231-3247.

111. Caracciolo G, Caputo D, Pozzi D, Colapicchioni V, Coppola R. Size and charge of nanoparticles following incubation with human plasma of healthy and pancreatic cancer patients. Colloids Surf B Biointerfaces. 2014;123:673-678.

112. Hajipour MJ, Laurent S, Aghaie A, Rezaee F, Mahmoudi M. Personalized protein coronas: a "key" factor at the nanobiointerface. Biomat Sci. 2014;2(9):1210-1221.

113. Peng $\mathrm{Q}, \mathrm{Mu} \mathrm{H}$. The potential of protein-nanomaterial interaction for advanced drug delivery. J Control Release. 2016;225:121-132.

114. Zanganeh S, Spitler R, Erfanzadeh M, Alkilany AM, Mahmoudi M. Protein corona: opportunities and challenges. Int J Biochemist Cell Biol. 2016;75:143-147.

115. Mahon E, Salvati A, Bombelli FB, Lynch I, Dawson KA. Designing the nanoparticle-biomolecule interface for "targeting and therapeutic delivery." J Control Release. 2012;161(2):164-174.

116. Hamad-Schifferli K. Exploiting the novel properties of protein coronas: emerging applications in nanomedicine. Nanomedicine (Lond). 2015; 10(10):1663-1674.
117. Schuchard M, Melm C, Crawford H, et al. Specific depletion of twenty high abundance proteins from human plasma. Paper presented at: NCI Proteomic Technologies Reagents Resource Workshop; December 12-13;2005; Chicago, IL.

118. Mu Q, Liu W, Xing Y, et al. Protein binding by functionalized multiwalled carbon nanotubes is governed by the surface chemistry of both parties and the nanotube diameter. J Phys Chem C. 2008;112(9): 3300-3307.

119. Lundqvist M, Sethson I, Jonsson BH. Protein adsorption onto silica nanoparticles: conformational changes depend on the particles' curvature and the protein stability. Langmuir. 2004;20(24):10639-10647.

120. Xu F, Reiser M, Yu X, Gummuluru S, Wetzler L, Reinhard BM. Lipid-mediated targeting with membrane-wrapped nanoparticles in the presence of corona formation. ACS Nano. 2016;10(1):1189-1200.

121. Walkey CD, Olsen JB, Guo H, Emili A, Chan WC. Nanoparticle size and surface chemistry determine serum protein adsorption and macrophage uptake. J Am Chem Soc. 2012;134(4):2139-2147.

122. Tenzer S, Docter D, Rosfa S, et al. Nanoparticle size is a critical physicochemical determinant of the human blood plasma corona: a comprehensive quantitative proteomic analysis. ACS Nano. 2011; 5(9):7155-7167.

123. Gagner JE, Lopez MD, Dordick JS, Siegel RW. Effect of gold nanoparticle morphology on adsorbed protein structure and function. Biomaterials. 2011;32(29):7241-7252.

124. Chellat F, Merhi Y, Moreau A, Yahia L. Therapeutic potential of nanoparticulate systems for macrophage targeting. Biomaterials. 2005;26(35):7260-7275

125. Gessner A, Waicz R, Lieske A, Paulke BR, Mäder K, Müller R. Nanoparticles with decreasing surface hydrophobicities: influence on plasma protein adsorption. Int J Pharm. 2000;196(2):245-249.
International Journal of Nanomedicine

\section{Publish your work in this journal}

The International Journal of Nanomedicine is an international, peerreviewed journal focusing on the application of nanotechnology in diagnostics, therapeutics, and drug delivery systems throughout the biomedical field. This journal is indexed on PubMed Central, MedLine, CAS, SciSearch $®$, Current Contents $\AA /$ Clinical Medicine,

\section{Dovepress}

Journal Citation Reports/Science Edition, EMBase, Scopus and the Elsevier Bibliographic databases. The manuscript management system is completely online and includes a very quick and fair peer-review system, which is all easy to use. Visit http://www.dovepress.com/ testimonials.php to read real quotes from published authors. 